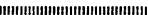

\section{Dimension Control of Workpieces on the Machining of Bearing Steel in Supercooled Austenite}

\author{
Yasuo Fujroka and Hiroshi Muro
}

\begin{abstract}
Synopsis :
On machining of bearing steel in supercooled austenite, the dimensions of a workpiece change due to the thermal contraction and the martensitic transformation in the cooling process after cutting.

In order to obtain the precise dimensions of the workpiece at room temperature, it is necessary to predict the dimension changes and to adjust the tool paths to compensate for them in the machining process of the steel in supercooled austenite. A method to predict the dimension change was estabished. A dimension control system for an NC machine tool was designed and its performance was proved by experiments.

The obtained results are summarized as follows;

(1) The thermal contraction rate of supercooled austenite of bearing steel SUJ3 is $2.2 \times 10^{-5} /{ }^{\circ} \mathrm{C}$.

(2) The final dimension $(L)$ of a workpiece is expressed by the following equation in terms of the temperature $\left(T^{\circ} \mathrm{C}\right)$ of the workpiece during cutting and the machined dimension $(l)$ of supercooled austenite. $L=l\left(1.0077-2.2 \times 10^{-5} \times T\right)$

(3) In the case when the tool wear rate is small, the final dimension is controled precisely by means of the developed dimension control system which makes the compensation of the machining dimension for the dimension change predicted at each temperature of workpieces on the basis of the thermal contraction rate of supercooled austenite.
\end{abstract}

\section{1. 緒言}

高炭素クロム軸受鋼を用いて軸受部品を製造する工程 は，例えばベアリングレースについては圧延素材一熱間 鍛造一焼なむし一切削加工一焼入れ・焼もどし一研削加工と いらのが一般的である. この工程には多くの加熱冷却 工程が含まれており，熱エネルギーの省略を図りたいが 高炭素鋼といら素材の本質上，上記の工程をとらざるを 得ないのが現状である．また，焼入れの際に発生する変 形のため，研削代を多くとらざるを得ず，これも熱エネ ルギー及び研削加工対策が必要な点のひとつであつた.

これに対して著者らはすでにオースカッティングと称 する方法を考案し，提案した . それは Fig. 1 に示し たように, 焼入れの祭に $M_{\mathrm{S}}$ 点直上の温度で泠却を中 断し，その状態（過冷オーステナイト）で切削加工を行 い, その後に再び冷却を行つてマルテンサイト変態を完 了させようとするものである。この方法によれば切削加 工前の焼なましが省略できるばかりでなく，適切な切削

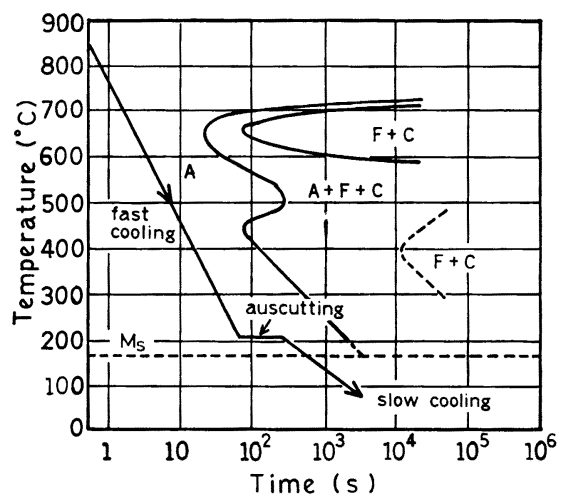

Fig. 1. TTT diagram of SUJ 3 and auscutting.

条件を選ぶことにより研削代の低減を図ることができる 可能性がある．著者らはこの方法が原理的に可能である ことをすでに見出していたので，本報では材料の熱収縮 や変態膨張を考慮に入れた寸法精度の制御法を確立した 結果について述べる.

昭和 57 年 9 月本会講演大会にて発表 昭和 58 年 5 月 23 日受付 (Received May 23，1983)

* エヌ・テー・エヌ東洋ベアリング(株) (NTN Toyo Bearing Co., Ltd., 1380 Higashikaizuka Iwata Shizuoka pref. 438)

*2 エヌ・テー・エヌ東洋ベアリング(株) 工博 (NTN Toyo Bearing Co., Ltd.) 


\section{2. オースカッティング方法と熱収縮及び変 態膨張による寸法変化の測定}

\section{$2 \cdot 1$ 試験片及び実験方法}

試験片として高炭素クロム軸受鋼 (SUJ3) の軸受素材 （ラジアル玉軸受 $6320 \dagger$ 内輪 : 外径 $138 \mathrm{~mm}$, 内径 95 $\mathrm{mm}$, 愊 $50 \mathrm{~mm}$ ) 用いた. SUJ3 の化学組成は Table 1 に示すごとくである. 本試験片（ワークピース，以後ワ 一クと略記する）はローリング鍛造法により作製し，鍛 造後従来ど扔りの球状化焼なましを施した妇の（硬度 HB 190) であるお2.

Table 1. Chemical compositions of SUJ 3.

\begin{tabular}{ccccccc}
\hline $\mathrm{C}$ & $\mathrm{Si}$ & $\mathrm{Mn}$ & $\mathrm{P}$ & $\mathrm{S}$ & $\mathrm{Cr}$ & $\mathrm{Mo}$ \\
\hline $0.95-1.10$ & $0.40-0.70$ & $0.90-1.15$ & $<0.025$ & $<0.025$ & $0.90-1.20$ & -
\end{tabular}

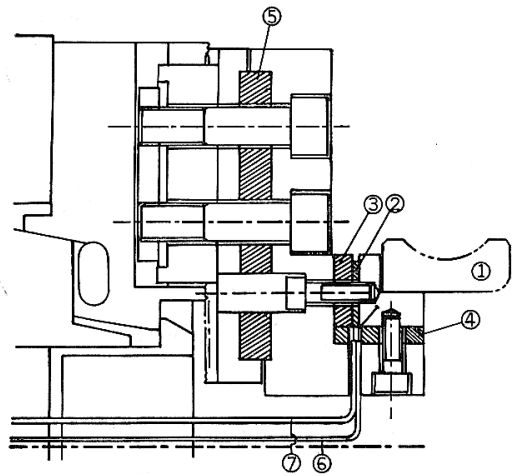

(1) workpiece (2) ceramic heater (3)(4)(5) insulating material (6) thermocouple (7) heater lead wire

Fig. 2. Insulated chuck.

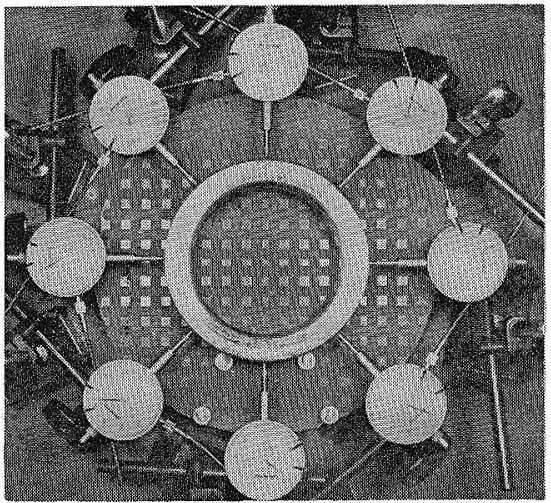

Photo. 1. Measuring device of dimension change after auscutting.

†単列樑みぞ玉帆受の呼び番号で，蚶受内径，外径及び幅寸法はそれ ぞれ $100 \mathrm{~mm}, 215 \mathrm{~mm}, 47 \mathrm{~mm}$ のものである.

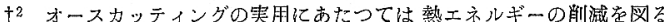

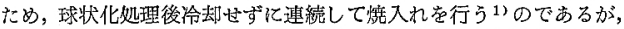
本研究は切削における寸法制御が主眼であるので徒来工程の球状化

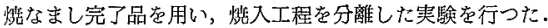

ワークを電気炉中で $825^{\circ} \mathrm{G} \sim 900^{\circ} \mathrm{G}$ の燒入温度に約 $50 \mathrm{~min}$ 加熱した後, $200^{\circ} \mathrm{C}$ の油中に急速冷却を行い過 冷オーステナイト状態とした. 油中に約 $3.5 \mathrm{~min}$ 保持 し，ワーク温度が $M_{\mathrm{s}}$ 点直上の約 $220^{\circ} \mathrm{C}$ になつた時

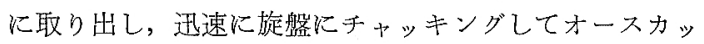
ティングを実施した. 切削条件については $3 \cdot 2 \cdot 2$ 項で 詳述するが，本報ではずで同一条件とした．切削中に ワーク温度が低下しない上ら，Fig. 2 に示すような試 作したセラミックヒーター内蔵の保温チャックを用い た.オースカッティング終了後 Photo. 1 亿示した装置 上にワークをセットし，空中放冷状熊で外径部に和ける 温度及び寸法の变化量を計測した。ワークの支持部には 耐䓡性のエポキシ樹脂積層板を使用し，部分的にワーク が冷却されるのを防いだ. 温度測定は接触式表面温度計 を用いて行い，寸法変化はダイヤルゲージの指示の変化 を写真撮影して語み取つた。

\section{$2 \cdot 2$ 実験結果}

Fig. 3 亿加熱温度 $850^{\circ} \mathrm{C}$ から $M_{\mathrm{s}}$ 点直上まで急冷 し，オースカッティングを実施した後のワーク温度一寸 法変化曲線を示す。オースカッティング終了直後のワー ク温度は約 $220^{\circ} \mathrm{C}$ であり, 加工中（ワークを油中から 取り出してから加工完了までの時間は約 3 min である) の温度低下はなかつた。これは保温チャックの爪部温度 を約 $220^{\circ} \mathrm{G}$ 飞制御して用いた効果であり，ワークとチ ヤック間の熱移動がない場合は，切削により加わる熱量 と空中への放熱量が注湾等しくなつていると考古られ る. 切削加工後の外径寸法は $135.5 \mathrm{~mm}$ であり, ワーク の冷却に伴い約 $170^{\circ} \mathrm{C}$ までは一定の割合で寸法が収縮 しその後膨張している. 加熱温度 $850^{\circ} \mathrm{C}$ の場合はこの

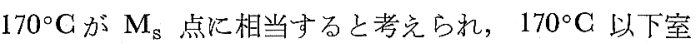
温まで冷却される間にマルテンサイト変態により体積膨 張が起こり，寸法は増大している．図中にワーク円周上

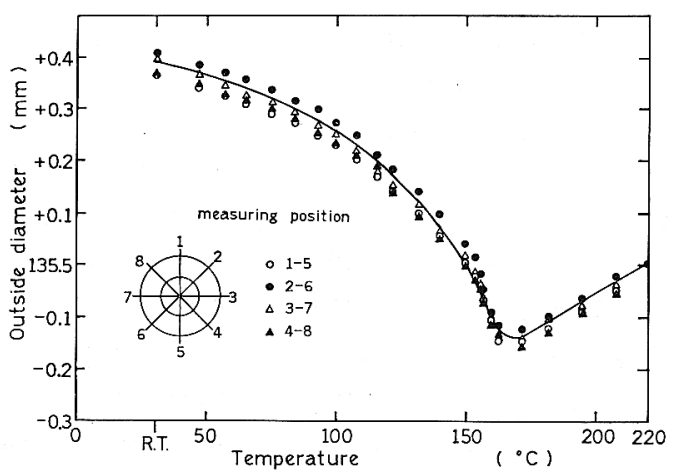

Fig. 3. Dimension change after auscutting at $220^{\circ} \mathrm{C}$, quenched from $850^{\circ} \mathrm{C}$. 


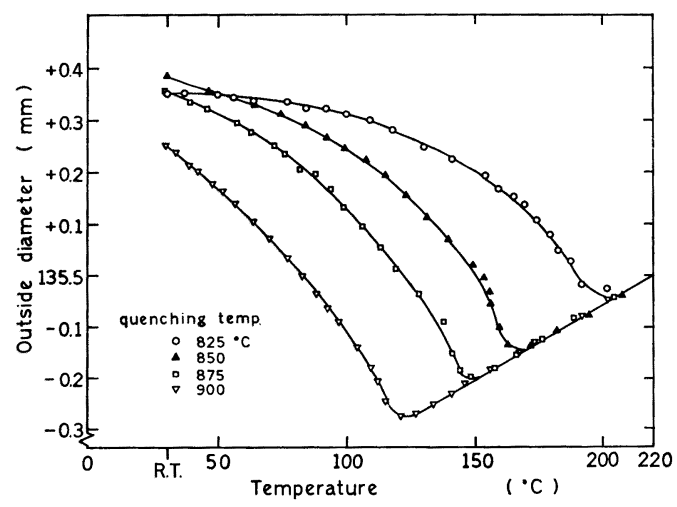

Fig. 4. Dimension change after auscutting in various quenching temperature from 825 to $900^{\circ} \mathrm{C}$.

で $45^{\circ}$ 間隔に分割した測定位置での寸法変化量を示した が，加工直後は真円であつたのに対し焼入硬化完了後で は約 $0.04 \mathrm{~mm}$ の焼入変形 (最大寸法-最小寸法)が認め られる。

Fig. 4 は $45^{\circ}$ 間隔での外径寸法測定值の平均值を求 め, 焼入加熱温度が $825^{\circ} \mathrm{C} \sim 900^{\circ} \mathrm{C}$ と変化した場合の 収縮から膨張への外径の変化を示す. 焼入加熱温度が変 化しても $M_{\mathrm{s}}$ 点までは一定の割合で収縮しており，同 図より過冷オーステナイトの熱收縮率 $\left(\Delta l / l \cdot{ }^{\circ} \mathrm{C}\right)$ を読み 取ると $2.2 \times 10^{-5} /{ }^{\circ} \mathrm{C}$ である. 焼入加熱温度が $825^{\circ} \mathrm{C}$, $850^{\circ} \mathrm{C}, 875^{\circ} \mathrm{C}, 900^{\circ} \mathrm{C}$ と上昇すると $M_{\mathrm{s}}$ 点はそれぞ れ $200^{\circ} \mathrm{C}, 170^{\circ} \mathrm{C}, 145^{\circ} \mathrm{C}, 120^{\circ} \mathrm{C}$ と低下し, 最終仕上 がり寸法にも多少の差が認められる. 最終仕上がり寸法 は加熱温度 $850^{\circ} \mathrm{C}$ の場合が $+0.39 \mathrm{~mm}$ と最大で, 加 熱温度 $900^{\circ} \mathrm{C}$ の場合が $+0.25 \mathrm{~mm}$ と最小になつてい るものの, 加熱温度 $825^{\circ} \mathrm{C}, 850^{\circ} \mathrm{C}, 875^{\circ} \mathrm{C}$ の值を比較 するとその差はわずか $0.03 \mathrm{~mm}$ であり軸受鋼の実用焼 入加熱温度範囲 $\left(800^{\circ} \mathrm{C} \sim 850^{\circ} \mathrm{C}\right)$ では多少焼入加熱温度 が変化してもほぼ一定值になると考えられる，従つて実 用上, 最終仕上がり寸法 $(L)$ は, Fig. 4 より切削寸 法 $(l)$ と切削開始時のワーク温度 $(T)$ を用いて $(1)$ 式のように表すことができるので，切削条件を一定と し，切削開始時のワーク温度を一定に管理すれば最終仕 上がり寸法を一定にすることができると考えられる.

$$
L=l\left(1.0077-2.2 \times 10^{-5} \times T\right)
$$

軸受鋼は焼入れ後通常 $150^{\circ} \mathrm{G} \sim 180^{\circ} \mathrm{G}$ の焼もどしを 実施するが, 焼もどしの際にも組織変化に伴う寸法変化 (収縮)が起こる・焼もどしによる収縮量は焼入れによる 寸法変化量に比べてはるかに小さい(例えば $180^{\circ} \mathrm{C} \times 2 \mathrm{~h}$ の条件では寸法収縮率 $\left.\Delta l / l=3.0 \times 10^{-4}\right) \quad$ が，研削代を 厳密に管理する場合はその収縮量を考慮に入れた寸法を

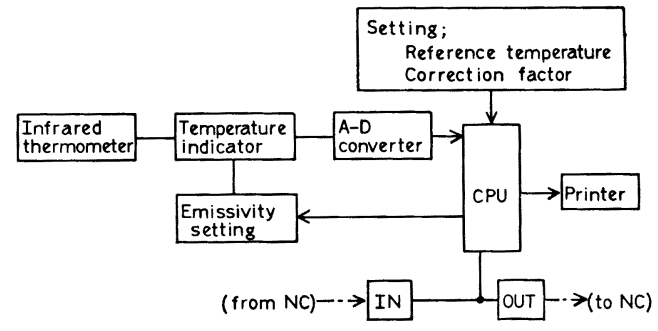

Fig. 5. Dimension control sytsem.

最終仕上がり寸法として設定すればよいと考えられる.

\section{3. 寸法制御実験}

\section{$3 \cdot 1$ 寸法制御方法}

切削開始時のワーク温度は，実際の製造ライン工程に おいては焼入作業による冷却条件の変動あるいはワーク 搬送中の温度低下等の要因により $20^{\circ} \mathrm{C} \sim 30^{\circ} \mathrm{C}$ 変動する ことが考えられる. そこで切削開始時のワーク温度が多 少変化しても所要の仕上がり寸法になるよらに制御する 方法を考案し，オースカッティングに护ける寸法制御を 試みた. すなわち, 切削開始時のワーク温度を計測し, 基準温度（オースカッティングを実施するのに最適なワ 一ク温度を基準温度とする）に対する温度差を工具位置 の補正量として寸法変化量に演算補正をして切削加工を 実施する方法である.

Fig. 5 に寸法制御システムの構成概要を示す. ワー クの表面温度を非接触で計測できる赤外線温度計と, 温 度測定值をある設定された基準温度と比較してその温度 差を寸法に演算変換して NG 旋盤の各工具位置補正部 へ伝達する中央情報処理部 (CPU) とから成つている. CPUへの設定入力としては基準温度と補正係数があり, 補正係数はワーク各部の切削寸法に前章の実験により求 まつた過冷オーステナイトの熱収縮率 $2.2 \times 10^{-5}$ を乗じ た值を用いる。

本寸法制御方法はオースカッティングに特有の, ワー ク温度が高いために生ずる加工時のワーク温度の変動を 補正するものであり，工具摩耗により生ずる切削寸法の 変化に対しては補正を行つていない，工具摩耗に関する 補正手段は別途検討することとし，本研究では切削終了 後のワーク温度を計測することにより工具摩耗が仕上が り寸法精度に及ぼす影響を調查した。

\section{$3 \cdot 2$ 実験方法}

$3 \cdot 2 \cdot 1$ 試験片及び熱処理条件

試験片として寸法変化量の測定実験で使用したものと 同一の 6320 内輪軸受素材ワーク (SUJ3) を用いた。熱 処理条件としては, 電気炉中で $850^{\circ} \mathrm{C} \times 50 \mathrm{~min}$ 保持し 

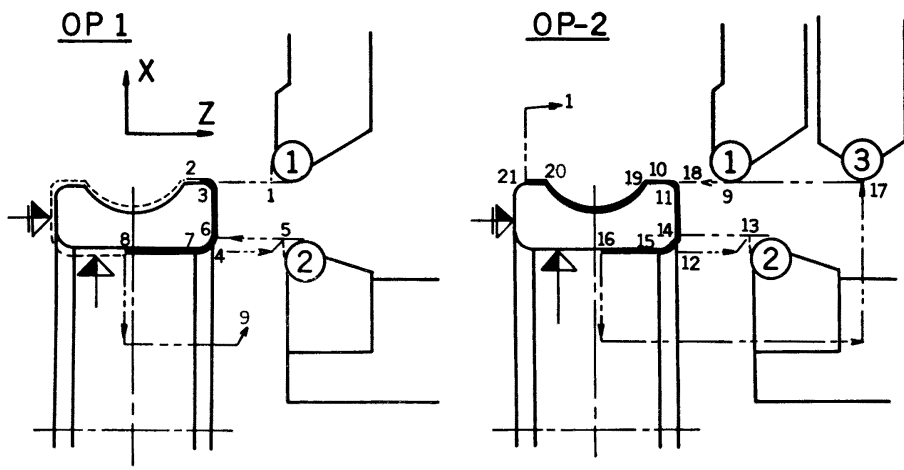

Fig. 6. Process drawing for cutting operation.
た後油中に急速冷却を行つた. 温度補正の効果を明確に する目的で, 切削開始温度が大きく変化するように焼 入油温度と保持時間はワーク No. 1 , No. 2 は $200^{\circ} \mathrm{G}$ $\times 3.5 \mathrm{~min}$, No. 3 , No. 4 は $180^{\circ} \mathrm{C} \times 4 \mathrm{~min}$, No. 5 No. 14 は $180^{\circ} \mathrm{C} \times 3.5 \mathrm{~min}$ と変化させた.

[ $3 \cdot 2 \cdot 2$ 切削条件

切削条件を以下に示す. また切削加工工程図を Fig.

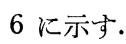

切削速度 : $V=200 \mathrm{~m} / \mathrm{min}$

送り量 $: f=0.2 \mathrm{~mm} / \mathrm{rev}$

切り达み量: $t=1.5 \mathrm{~mm}$ (ローリング鍛造ワークを

1 回削りで所要寸法に仕上げる)

工具 : 黒セラミック工具（直径 $12.7 \mathrm{~mm}$ の丸 型) 前すくい角 $\left(\alpha^{\circ}\right)$

(1) $\alpha=-6^{\circ}$ (幅切削工具)

(2) $\alpha=-9^{\circ}$ (内径切削工具)

(3) $\alpha=-8.5^{\circ}$ (外径切削工具)

切削状態: 乾式切削

なお，工具として黒セラミック工具を選んだ理由は， 過冷オーステナイトは硬度が HB 230 程度と比較的低 いにもかかわらず切削時の刃先温度が高温となるため, 超硬工具では工具摩耗が著しく短寿命であり，オースカ ッティング用工具として黒セラミック工具が最適であつ た1)からである。

\section{$3 \cdot 2 \cdot 3$ 設定值}

寸法制御システムへの設定入力として本実験では次の ようにした.オースカッティング時の最適ワーク温度範 囲は加熱温度 $850^{\circ} \mathrm{C}$ の場合, $M_{\mathrm{s}}$ 点直上の $170^{\circ} \mathrm{C} \sim$ $230^{\circ} \mathrm{C}$ であるのでその中間の $200^{\circ} \mathrm{C}$ を基準温度とし た。

$$
\begin{array}{ll}
\text { 基準温度 } & : 200^{\circ} \mathrm{G} \\
\text { 各工具の補正 }: & G_{1}=3.0 \text { (工具(1)の } \mathrm{X} \text { に対応) } \\
\text { 係数 }(G) & G_{2}=2.2 \text { (工具(2)の Xに対応) } \\
& G_{3}=3.0 \text { (工具(3)の X } \text { 対応) }
\end{array}
$$

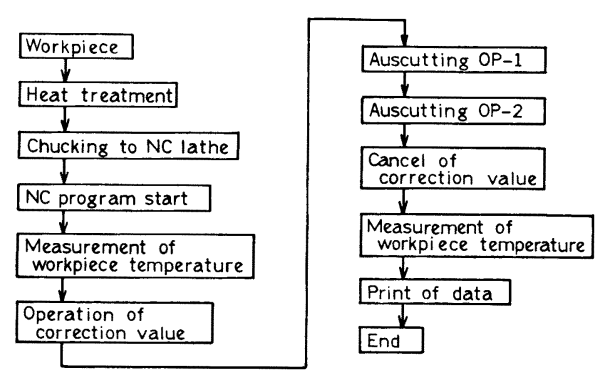

Fig. 7. Experimental procedure for dimension control.

$$
G_{4}=1.1 \text { (工具 (1), (2), (3)の } \mathrm{Z} \text { に対 }
$$

赤外線温度計 : $\varepsilon_{1}=0.93$ (切削前の黒皮状態)

の放射率 $(\varepsilon) \quad \varepsilon_{2}=0.45$ (オースカッティング 後の 切削面)

補正係数 $G$ は切削各部の寸法に過冷オーステナイトの 熱収縮率を乗じて求めたものであり, 例えば外径部切削 の場合は $135.5 \times 2.2 \times 10^{-5} \fallingdotseq 3.0 \times 10^{-3}$ となり $G_{3}=$ 3.0 は $1^{\circ} \mathrm{C}$ の温度変化に対して $3.0 \mu \mathrm{m}$ の工具位置補 正を行らことを意味する. 赤外線温度計の放射率 $\varepsilon$ は切 削加工前後の表面状態の差異によつて異なり, それぞれ 熱電対式の表面温度計を用いて実験により決定した.

\section{$3 \cdot 2 \cdot 4$ 実験手順}

寸法制御実験の手順を Fig. 7 に示す. ワーク個数は 14 個 (No. 1 No. 14) とし, 同一切削条件にて行つ た. 寸法制御は個々のワークに対して単独に行い, 演算 された補正值はそのつどキャンセルされる.データとし て切削開始前及び切削終了後のワーク温度を印字する. 切削終了後直ちにワークの切削寸法を計測し, 室温まで 完全に空冷した後再び寸法計測を行ら.

\section{3 .3 実験結果}

Fig. 8 に寸法測定結果とオースカッティング 開始時 及び終了時のワーク温度を示した. 寸法測定は外径及び 


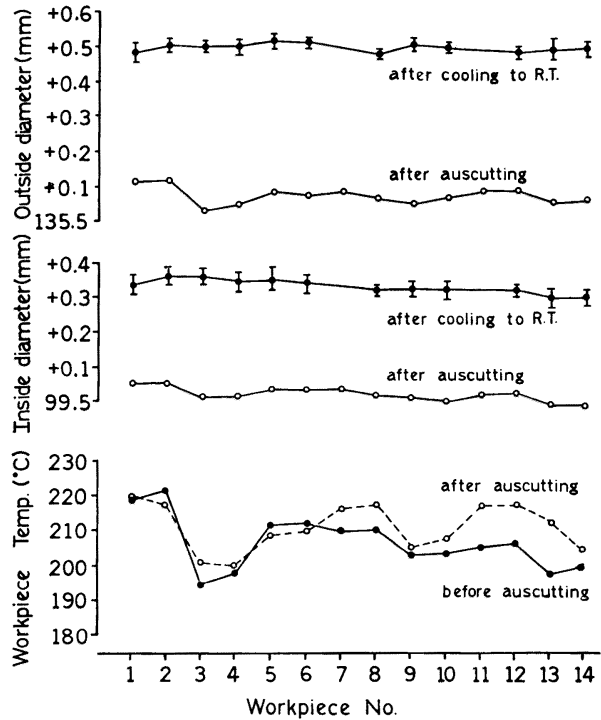

Fig. 8. Relationship between dimension and workpiece temperature.

内径について行い, 図中○印はオースカッティング終了 直後の切削寸法を, ○印は室温まで空冷し焼入硬化が終 了（硬度：HRC 64.5～65） した後の寸法を示す。また I印で示した幅は焼入変形を表している.

オースカッティング終了後室温まで空冷した後の最終 仕上がり寸法は外径及び内径ともに $0.05 \mathrm{~mm}$ 以内の変 動範囲におさまつており,切削開始時のワーク温度が 30 ${ }^{\circ} \mathbf{C}$ 程度変動しても本法による寸法制御の効果により, 従来工程での切削寸法公差 $( \pm 0.07 \mathrm{~mm})$ 内に沶さめる ことができる.焼入変形に関してもほぼ $0.05 \mathrm{~mm}$ 以下 であり切削を伴わない従来の焼入硬化熱処理品（通常 $0.1 \sim 0.15 \mathrm{~mm}$ の焼入変形がある）に比べて著しく小さ くなつている. 一方, 切削終了後のワーク温度に関して は，工具摩耗が少ない間は切削開始時とほとんど同じ温 度を示しているが 7 個目の切削あたりからしだいに温度 が $5^{\circ} \mathrm{C} \sim 10^{\circ} \mathrm{C}$ 程度高くなり始め, 工具摩耗による影響 が認められるようになる。

\section{4. 考察}

\section{$4 \cdot 1$ 仕上がり寸法精度に及ぼす工具摩耗の影響}

\section{$4 \cdot 1 \cdot 1$ 工具摩耗が少ない場合}

14 個のワークにつき寸法制御実験を行つた 結 果, 最 終仕上がり寸法の変動は $0.05 \mathrm{~mm}$ 以内におさまつてお り，切削開始時のワーク温度の変動を補正するといら制 御方式だけで十分所要の寸法精度（目標值は従来方法で の切削品の寸法公差内で $\pm 0.07 \mathrm{~mm}$ ) が得られた. 14 個切削終了後の工具摩耗は逃げ面摩 耗幅 $\left(V_{\mathrm{B}}\right)$ で表す
Table 2. Comparison of final dimension between measured and calculated value.

\begin{tabular}{|c|c|c|c|c|c|}
\hline \multirow{2}{*}{$\begin{array}{l}\text { Work- } \\
\text { piece } \\
\text { No. }\end{array}$} & \multirow{2}{*}{$\begin{array}{l}\text { Workpiece } \\
\text { temp. } \\
\left({ }^{\circ} \mathrm{C}\right)\end{array}$} & \multirow{2}{*}{$\begin{array}{c}\text { Machining } \\
\text { dimension } \\
(\mathrm{mm})\end{array}$} & \multicolumn{3}{|c|}{ Final dimension $(\mathrm{mm})$} \\
\hline & & & $\begin{array}{c}\text { Calculated } \\
D_{c}\end{array}$ & $\begin{array}{c}\text { Measured } \\
D_{\mathrm{m}}\end{array}$ & $D_{\mathrm{m}}-D_{\mathrm{c}}$ \\
\hline 2 & 222 & $\begin{array}{lr}\text { O. } & 135.62 \\
\text { I. } & 99.55\end{array}$ & $\begin{array}{r}136.00 \\
99.83\end{array}$ & $\begin{array}{r}136.01 \\
99.86\end{array}$ & $\begin{array}{l}+0.01 \\
+0.03\end{array}$ \\
\hline 4 & 198 & $\begin{array}{cr}\text { O. } & 135.55 \\
\text { I. } & 99.51\end{array}$ & $\begin{array}{r}136.00 \\
99.84\end{array}$ & $\begin{array}{r}136.00 \\
99.84\end{array}$ & $\begin{array}{l}0 \\
0\end{array}$ \\
\hline 6 & 212 & $\begin{array}{lr}\text { O. } & 135.58 \\
\text { I. } & 99.53\end{array}$ & $\begin{array}{r}135.99 \\
99.83\end{array}$ & $\begin{array}{r}136.02 \\
99.83\end{array}$ & $+\underset{0}{+0.03}$ \\
\hline
\end{tabular}

O. outside diameter I. inside diameter

と, 外径工具 : $V_{\mathbf{B}}=0.05 \mathrm{~mm}$, 内径工具 : $V_{\mathbf{B}}=0.1 \mathrm{~mm}$ と比較的小さく, 工具摩耗が少ない場合には本研究で実 施した寸法制御方式で, 切削開始時のワーク温度が变化 しても実用上十分な寸法精度が得られる。

ド切削開始時のワーク 温度の 変動が大きいワーク No. 2, No. 4, No. 6 について最終仕上がり寸法と実験で 求まつた(1)式での計算值を比較すると Table 2 のよ らになる．外径寸法及び内径寸法共に実測值と計算值と は良く一致しており，（1）式の妥当性が証明できたと同 時に，(1)式を用いれば所要の最終仕上がり寸法に対し てオースカッティングにおける切削開始温度と切削寸法 を計算により決定できることになる。

また，焼入硬化熱処理に特有の焼入変形に関してもほ ぼ $0.05 \mathrm{~mm}$ 以内におさまつており従来工程での焼入品 よりも寸法精度が向上している.これは，オースカッテ ィングに扣いては焼入加熱時の変形及び焼入冷却時の変 形がすべて切削加工により除去されるためであり, 研削 代を削減することが可能となる. 具体的には, 従来研削 代を $0.4 \mathrm{~mm}$ 程度見込まざるを得なかつたのに対し, 本 制御方式によるオースカッティングを実施することによ り $0.2 \mathrm{~mm}$ 程度に削減でき, 研削能率が向上した.

$4 \cdot 1 \cdot 2$ 工具摩耗が多い場合

工具摩耗が多くなつた場合の寸法制御状況を調べる目 的で，前述の制御実験（ワーク No. 1〜No. 14）にひ きつづき, 同一制御方式, 同一切削条件で工具交換をせ ずにワーク No. 15〜No. 43 につきオースカッティン

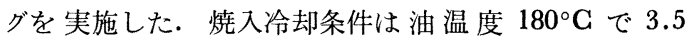
min 保持とした.

Fig. 9 に外径及び 内径の最終仕上がり寸法の変化, 工具摩耗量の変化及びワークの温度上昇量（切削終了温 度一切削開始温度)の変化をまとめて示した．外径寸法， 内径寸法共に最終仕上がり寸法は加工個数の増大に伴い 小さくなる傾向が認められる. No. 1 から No. 43 まで の変化量は同図から外径寸法で $-0.06 \mathrm{~mm}$, 内径寸法で $-0.18 \mathrm{~mm}$ あり, 外径寸法に関しては工具摩耗が 進行 


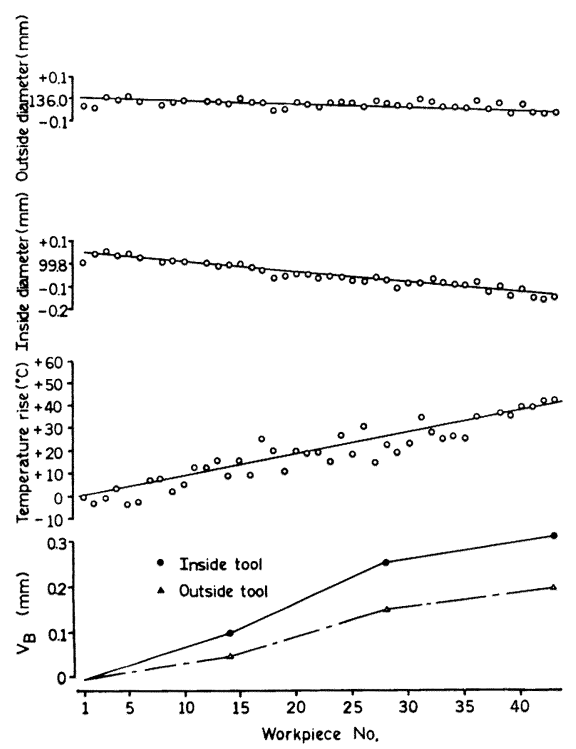

Fig. 9. Effect of tool wear on final dimension and temperature rise of workpiece.

してもその影響は小さく，本研究で試作した寸法制御シ ステムを用いた制御方式で十分所要の寸法公差内におさ まつている. 一方内径寸法に関しては所要の寸法公差内 に和さまらず，工具摩耗量を何らかの手段でさらに補正 をする必要がある.この現象は次のように解釈できる.

工具摩耗量は 43 個の切削終了後で外径工具, 内径工 具それぞれ $V_{\mathrm{B}}=0.2 \mathrm{~mm}, V_{\mathrm{B}}=0.3 \mathrm{~mm}$ であり切削寸法 に対する影響は，

外径 : $V_{\mathrm{B}} \times \tan \alpha^{\circ} \times 2=0.2 \times \tan 8.5^{\circ} \times 2 \leftrightharpoons 0.06 \mathrm{~mm}$ $\oplus$

内径 : $V_{\mathrm{B}} \times \tan \alpha^{\circ} \times 2=0.3 \times \tan 9^{\circ} \times 2 \fallingdotseq 0.10 \mathrm{~mm}$ $\ominus$

あつたと考えられる・

一方同図中に示したように工具摩耗量の増加に伴い, 切削による温度上昇量が増大し，43 個切削終了後では 約 $40^{\circ} \mathrm{C}$ になつている. この温度上昇量の寸法に対する 影響は，

外径 : $135.5 \times 2.2 \times 10^{-5} \times 40 \fallingdotseq 0.12 \mathrm{~mm}$

内径 : $99.5 \times 2.2 \times 10^{-5} \times 40 \fallingdotseq 0.09 \mathrm{~mm}$ あつたと考えられる。

以上最終仕上がり寸法には刃先摩耗の影響及び温度上 昇の影響の両方が現れてくるため，43 個目のワークは 1 個目のワークと比較して

外径 : $+0.06-0.12=-0.06 \mathrm{~mm}$

内径 : $-0.10-0.09=-0.19 \mathrm{~mm}$ の影響があると考えられ，実測值と良く一致する。

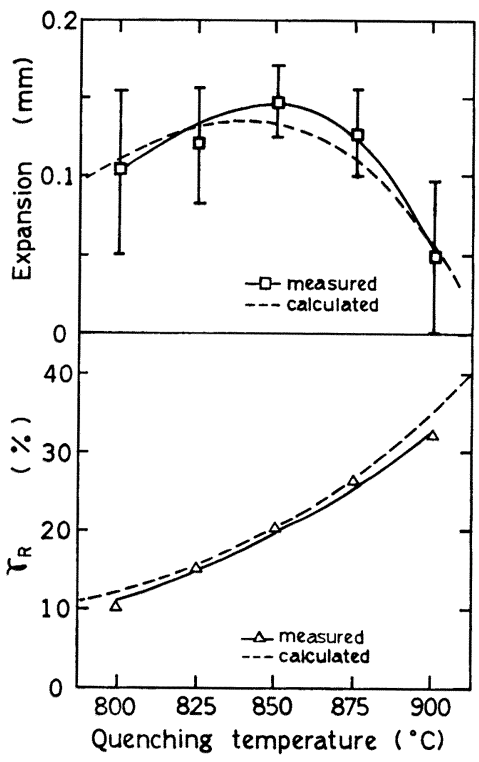

Fig. 10. Effect of quenching temperature on dimension change and retained austenite $\left(\gamma_{R}\right)$.

工具摩耗が多くなつた場合の寸法補正手段としては, 通常の切削方法において用いられているよらな工具位置 を種々の検出器により検出して摩耗量を補正することも 有効であるが，オースカッティングにおいては Fig. 9 中に示したように工具摩耗量と切削によるワークの温度 上昇量にはほぼ比例関係が認められることより，ワーク の温度上昇量を検出することにより工具摩耗量を推定す る方法が有効であると考えられる.

\section{$4 \cdot 2$ 焼入加熱温度の寸法変化に及ぼす影響}

Fig. 4 に示したように一定温度で切削加工した場合 でも, 焼入加熱温度が変化すればマルテンサイト変態終 了後の最終仕上がり寸法には多少の差が認められた.こ の現象は残留オーステナイト $\left(\gamma_{\mathrm{R}}\right)$ 量と関係があると考 えられ，別形状の試験片を用い焼入硬化熱処理による寸 法変化量と $\gamma_{\mathrm{R}}$ 量の関係を調べ, 焼入加熱温度の寸法変 化に及ぼす影響を考察した。

前述の軸受素材 (SUJ3) から外径 $120 \mathrm{~mm}$, 内径 100 $\mathrm{mm}$, 幅 $20 \mathrm{~mm}$ のリング形状試片を作製し, 焼入硬化 熱処理（熱処理方法はオースカッティングを実施する場 合と同じ）に拈ける外径寸法の变化量及び $\gamma_{\mathrm{R}}$ 量を測定 した. $\gamma_{\mathrm{R}}$ 量は X 線により測定し， $\gamma(220), \alpha(211)$ 面 の回折強度から求めた.

Fig. 10 に焼入加熱温度が $800^{\circ} \mathrm{C} \sim 900^{\circ} \mathrm{C}$ と変化した 場合の寸法変化量 (膨張量) 及び $\gamma_{\mathrm{R}}$ 量の測定結果を示 した. 寸法変化量に関しては焼入変形が大きいが，平均 值で比較すると加熱温度 $850^{\circ} \mathrm{C}$ の場合に寸法膨張量が 
最も大きく極大を示し, $850^{\circ} \mathrm{C}$ よりも低くても高くても 寸法膨張量は小さくなつている.一方, $\gamma_{\mathrm{R}}$ 量は焼入加 熱温度の上昇に伴い多くなつている.

軸受鋼の 焼入組織はマルテンサイト $+\gamma_{\mathrm{R}}+$ 未溶解炭 化物の 混合組織であり基質中に 固溶する炭素量は焼入 加熱温度により異なる．佐藤らによれば $\mathrm{Cr} 3 \%$ 以下， $\mathrm{Mn} 3 \%$ 以下の鋼では炭化物は $(\mathrm{Fe} \cdot \mathrm{M})_{3} \mathrm{C}$ となり ${ }^{2)}$ 炭素 鋼の場合と大差ないと考兄られるので，以下炭素鋼にお ける計算式を用いて考察する。

オーステナイトあるいはマルテンサイトに固溶してい る炭素の重量パーセント $(\% \mathrm{G})$ は鋼の炭素重量パーセ ントを \% $\mathrm{C}_{\mathrm{T}}$ ，セメンタイトの容量パーセントを $V_{\mathrm{c}}$ と すれば(2)式の関係で表される3).

$$
\% \mathrm{C}=\frac{\% C_{\mathrm{T}}-0.067 V_{\mathrm{c}}}{1-0.01 V_{\mathrm{c}}}
$$

焼入れ後の組織観察の 結果, 残留炭化物量は $825^{\circ} \mathrm{C}$, $900^{\circ} \mathrm{C}, 925^{\circ} \mathrm{C}$ 加熱時においてそれぞれ約 7.5\%，2\%， $0 \%$ であつた。本実験に用いた試験片の \% $\mathrm{C}_{\mathrm{T}}$ は 1.02 であり，(2)式を用いて基質中に固溶している\% $\mathrm{C}$ を 計算し烧入加熱温度 $\left(T_{\mathrm{q}}\right)$ との関係を求めると, 両者に はほぼ比例関係が認められ(3)式のように表すことがで きる。

$$
\% \mathrm{C}=0.0046 T_{\mathrm{q}}-3.235
$$

KOISTINEN によれば炭素及び低合金鋼の焼入れの場 合, 室温 $20^{\circ} \mathrm{C}$ に打ける $\gamma_{\mathrm{R}}$ 量 (\%) はと材料の $M_{\mathrm{s}}$ 点に依存し，(4)式で表される ${ }^{4} . M_{\mathrm{s}}$ 点は Fig. 4 の実 験結果より焼入温度の関数として(5)式で表されるので $\gamma_{\mathrm{R}}$ 量も(6)式のように焼入加熱温度の関数として表せ る.

$$
\begin{aligned}
& \gamma_{\mathrm{R}}=\exp \left[-0.011\left(M_{\mathrm{s}}-20\right)\right] \times 100 \\
& M_{\mathrm{s}}=-T_{\mathrm{q}}+1020 \\
& \gamma_{\mathrm{R}}=\exp \left[-0.011\left(1000-T_{\mathrm{q}}\right)\right] \times 100
\end{aligned}
$$

(6) 式を用いて $T_{\mathrm{q}}=800^{\circ} \mathrm{C} \sim 900^{\circ} \mathrm{C}$ の温度範囲で $\gamma_{R}$ 量を計算した結果を Fig. 10 中に示したが，本実験での 実測値とよく一致している。

焼入れ時の組織変化に伴ら体積変化は LEMENT によれ ば,（フェライト十セメンタイト）、マルテンサイト， (フェライト十七メンタイト) $\rightarrow$ オーステナイトに変化 した時の体積変化量（\%) はそれぞれ固溶している炭素 量の関数として $(7),(8)$ 式のように表される5).

$$
\begin{aligned}
& \Delta V_{\mathrm{m}}=1.69(\% \mathrm{C}) \cdots \cdots \cdots . . . \\
& \Delta V_{\tau}=-4.64+2.21(\% \mathrm{C})
\end{aligned}
$$

従つて, 焼入れ後の体積変化量 $\Delta V$ は $(9)$ 式で表され ることになり, 寸法変化量 $\Delta l$ は焼入れ前の試片寸法を $l$ とすると(10)式で表される.

$$
\begin{aligned}
& \Delta V=\Delta V_{\mathrm{m}}\left(100-\gamma_{\mathrm{R}}\right)+\Delta V_{\gamma} \times \gamma_{\mathrm{R}} \cdots \\
& \Delta l=l \times \Delta V / 3 \ldots \ldots \ldots \ldots \ldots \ldots \ldots \ldots \ldots \ldots \ldots \ldots \ldots
\end{aligned}
$$

(10)式に(3)（6)（7）（8）(9)式を代入すると寸法変化 量は燒入加熱温度の関数として求まり，l=120 $\mathrm{mm}$ の場 合の計算結果を Fig. 10 中に示した. 寸法膨張量は加熱 温度 $840^{\circ} \mathrm{C}$ の場合に $0.14 \mathrm{~mm}$ と極大を示し, また $840^{\circ} \mathrm{C}$ 近辺の温度域では加熱温度が多少変化しても寸法 変化量の差は小さく, 本実験結果とほぼ一致している. 焼入加熱温度が高くなるとマルテンサイト变態による膨 張が大きくなると同時に $\gamma_{\mathrm{R}}$ 量も多くなり，寸法変化々 しては両者が相殺されるため, 実用燒入加熱温度範囲で は焼入加熱温度の寸法变化に及活寸影響は小さくなると 考觉られる。

\section{5. 結言}

焼入冷却途中の過冷オーステナイト状態で切削加工を 施すオースカッティングに打いて, 切削加工終了後の寸 法変化挙動を定量的に明らかにした。またとの結果得ら れた過冷オーステナイトの熱収縮率に基づき，切削開始 時のワーク温度が变化した場合でも最終仕上がり寸法を 精度良く一定寸法に制御する寸法制御方法を考案し, 実 験によりその効果を確めた。

得られたおもな結果は次のと抢りである.

1) SUJ3 に打ける焼入冷却途中の過冷オーステナイ 卜の熱収縮率は $2.2 \times 10^{-5} /{ }^{\circ} \mathrm{C}$ である.

2）焼入加熱温度が 変化すると $M_{\mathrm{s}}$ 点が変化し, 最 終仕上がり寸法も多少変化する．最終仕上がり寸法はマ ルテンサイトの体積膨張量と残留オーステナイト量との 関係により決まり, 加熱温度 $840^{\circ} \mathrm{C} \sim 850^{\circ} \mathrm{C}$ の場合が最 大寸法となる・しかしながら軸受鋼の実用焼入加熱温度 範囲においてはその差はわずかであり，ほぼ一定值にな ると考光てもさしつかえない，従つて，最終仕上がり寸 法 $(L)$ は切削寸法 $(l)$ と切削開始時のワーク温度 $(T)$ を用いて次式のように表すことができる.

$$
L=l\left(1.0077-2.2 \times 10^{-5} \times T\right)
$$

3 ) 工具摩耗量が少ない場合は, ワークの切削開始時 の温度変動を過冷オーステナイトの熱収縮率に基づいて 切削寸法を補正するという寸法制御方法を用いることに より, ワーク温度の変動が $30^{\circ} \mathrm{C}$ 程度あつた場合でも最 終仕上がり寸法を十分良好な精度に制御できる。また焼 入変形も著しく小さくなるので, 研削代を従来の製造工 程品の約 $1 / 2$ に削減することが可能となる.

4 ) 工具摩耗量が多くなつた場合には，刃先位置の変 化及び切削加工によるワークの温度上昇が発生するため 十分な精度が得られず，別途工具摩耗量の補正が必要と 
なる. 工具摩耗量を検出する手段としては, ワークの温 度上昇量を計測するのが有効である.

最後に本研究は昭和 56 年度通産省重要技術研究開発 試験研究の一つとして助成を受けたことを付記する。

\section{交}

\section{献}

1) Y. Fujioka, $H$. Tani, and $H$. Muro: Proc. Intern'l Symp. on Influence of Metallurgy on Machinability of Steel (1977), p. 323 [ISIJ.
ASM]

2 ) 佐藤知雄, 西澤泰二: 日本金属学会誌, 19(1955), p. 385

3 ) 田中実：鉄鋼材料便覧（日本金属学会，日本鉄鋼 協会編）(1979)，p. 122 [丸善]

4 ) D. P. Koistinen and R. E. Marburger: Acta Metall., 7 (1959), p. 59

5 ) B. S. Lement: Distortion in Tool Steels (1956) [ASM] 